Volume 11 Number 2, April-June 2017: pp. 122-132

Copyright (c) 2015-2016 FIAT JUSTISIA. Faculty of Law, Lampung University, Bandarlampung, Lampung, Indonesia. ISSN: $1978-5186$ | e-ISSN: 2477-6238.

Open Access: http://jurnal.fh.unila.ac.id/index.php/fiat

Fiat Justisia is licensed under a Creative Commons Attribution 4.0 International License, which permits unrestricted use, distribution, and reproduction in any medium, provided the original work is properly cited.

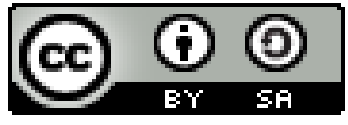

\title{
Positive Protection: Protecting Genetic Resources Related to Traditional Knowledge in Indonesia
}

\author{
Rohaini \\ Faculty of Law, University of Lampung \\ rohaini.arifien81@gmail.com \\ Nenny Dwi Ariani \\ Faculty of Law, University of Lampung \\ nennydwiariani@gmail.com
}

\begin{abstract}
Genetic Resources is a foundation of human life, as a source of food, industrial raw materials, pharmaceuticals, and medicines. From its utilization may provide a financial benefit to the provider and the user of it. Unfortunately, most of it obtained from developing countries through biopiracy, including Indonesia. Furthermore, in the early 1980s, access and benefit sharing $(A B S)$ to genetic resources became an international issue. It leads to the adoption of the Convention on Biological Diversity (CBD) in 1992. However, since it was approved, the whole ideas of excellence of it could not be implemented, a problem on it still arises. Intellectual property right laws, in certain aspects, are possible for using to protect traditional knowledge from their utilization. However, at the same time, intellectual property regime also becomes "a tool" to legitimate of biopiracy practices.

Due to massive international pressure, mostly in developing countries, it proposes two kinds of protections, which are positive protection and defensive protection. This paper will examine one of it, which is positive protection. By using the normative method and qualitative approach, this paper identified at least two kinds of positive protections that we can develop to protect genetic resources related to traditional knowledge, which are optimizing the patent law and developing the sui generis law. Furthermore, it can be done by some revision by adding new substances, an improvement on the articles, or even by doing the deletion on certain articles. Moreover, in order to develop the sui generis law, it identified several minimum elements that shall be contained on it, inter alia: the purposes of protection; scope of protection; criteria of protection; the beneficiaries of protection: the holder of traditional knowledge; the kind of rights to be
\end{abstract}


granted; how the rights acquired; how to enforce it; how the rights lost or expired; and dispute resolution.

Keywords: Positive Protection, Genetic Resources, Traditional Knowledge.

\section{A. Introduction}

Indonesia as a developing country that rich in natural resources, arts and culture have a wide range of traditional knowledge that requires legal recognition and protection as an internationally recognized work of the nation. Traditional Knowledge (TK) as one of the human life necessities comes from technologies and resources is vitally necessary for developing countries for the safety of food as well as people health.

Indonesia has values of economic from billion of Genetic Resources (GR) ${ }^{1}$ and traditional knowledge associated with genetic resources possessed. Based on the credential in the Republic of Indonesia Constitution, to use TK in a continuous way for Indonesian welfare, it has to be preserved and also widen. Since several reforms and implementations of TK have given meaningful support in human life, for instance, traditional agriculture, drugs, conservancy, conventional preference and methods of propagation, pest and disease supervision and others. Sharman Pharmaceutical is the example of the success of TK in modern industries comes from cosmetics and agriculture. It is a pharmaceutical company with the head office in San Francisco whose project of medicine invention process with ethnomedically that aims to discover new compounds as support to cure through TK utilization. This project was done by two certain tribes to treat a similar disease in comparative plants researches which are expected to lessen the research cost. ${ }^{2}$

\footnotetext{
${ }^{1}$ Genetic Resources (GRs) refer to the genetic material of actual or potential value. Genetic material is any material of plant, animal, microbial or other origin containing functional units of heredity. Examples include material of plant, animal, or microbial origin, such as medicinal plants, agricultural crops and animal breeds. http://www.wipo.int/tk/en/genetic/, accessed on 22-08-2017.

${ }^{2}$ Carsten Fink, Patent Protection, Transnational Corporations, and Market Structure: A Simulation Study of the India Pharmaceutical Industry, in Imas Rosidawati, (2013). "Konsep Perlindungan Pengetahuan Tradisional Berdasarkan Asas Keadilan melalui Sui Generis Intellectual Property System (The Concept of Traditional Knowledge Protection Based on the Principle of Justice through the Sui Generis of Intellectual Property System)". Jurnal Hukum Ius Quaiustum, 20(2): 163.
} 
The rapid development of modern biotechnology over the past decades has enabled us to use Genetic Resources (GR). Developments in GR should not be assumed as usual commodities anymore. It is owing to the use of GR as new products which support human prosperity, for example, sources of food into potent medicines and also GR along with commodities with commercial value is beneficial for noncommercial use:

a. For commercial use, GR profit can be obtained by the company to expand particular enzymes, genes and little molecules by changing to an advantageous product for human life, such as drugs;

b. For non-commercial use, utilizing GR can promote the environment and natural world awareness and concept in the research and analysis.

According to it, there is a difference between the potential of developed and developing countries to TK value. As developed countries view, the concern is getting the most knowledge access in new product creation and big commercial profits. At the same time, developing countries concern about mutual exchanging benefits of using TK associated with GR especially for countries with huge biodiversity and TK. Since TK is very fundamental, both developed and developing countries have agreed to preserve TK. It can be seen that TK has contributed in the economy and social life significantly, the knowledge value can empower identity of culture along with that kind of awareness with better utilization to reach the goals in social and development, for example, continual agriculture, cheap and proper health for the public, and biodiversity conservation. ${ }^{3}$ Furthermore, international agreement implementation between those countries can influence the way of preserving and spreading the knowledge related to GR utilization and also the way of secured protection of their national behalf. Also, TK has big potential in creating a continual expansion of economic in a lot of countries.

Besides the value of culture and history as mentioned before, TK also has the value of economic, so that TK needs to be preserved. Other reasons for TK protection is pervert committed by pharmaceutical companies and bio-seeker in gaining big profits where the companies hold several types of research beginning with the sort

\footnotetext{
${ }^{3}$ WIPO Publication No. 920 Booklet No. 2: Page 10. Available at Secretariat of WIPO.
} 
of TK possessed by aboriginal. ${ }^{4}$ Mostly these companies before getting patent rights on medical products, cosmetics, etc., they would conduct some research starting from a kind of $\mathrm{TK}$, which is owned by a group of indigenous people. This knowledge is often got without permission from the owner of the knowledge. Also, most of the owners sometimes do not get the benefit share from the utilization of it. These circumstances, in the end, encourage the spirit of several developing countries to demand justice for accessing and sharing the benefit (ABS).

There is no allowance from the owner in getting the knowledge, and also no benefits are sharing in using it. At last, developing countries are motivated in this state to require accessing and sharing benefits (ABS) fairness. Preserving, maintaining and widen TK need to be done caused by some reasons based on ABS implementation discussion below:

1. Deliberation of fairness

For commercial interest, fair compensation should be given to TK fancier

2. Conservation attention

This concern supports the Conservancy of the environment, biodiversity, and continual agricultural implementation

3. Traditional implementation and culture protection

Knowledge profile will be increased and entrust of people will come in communities through the use of TK protection

4. Avoiding unauthorized parties appropriation or biopiracy

Medical TK biopiracy can be decreased as well as confirming equal and just treatment of owner and user by TK preservation

5. TK utilization and significance for development endorsement

Moreover, instead of TK protection intends to restrict access, to avoid manipulation, endorsing the government should do TK utilization complimenting it by using measurement. ${ }^{5}$

International communities have a main concern about actions control of scientific and commercial aspects along with TK utilization with no acceptance and redeem. Attentions of TK drive it is going to be lost sooner in the end, since the loss can affect global cultural diversity loss and also conservancy and biodiversity.

\footnotetext{
${ }^{4}$ Graham Dutfield, (2006), Protecting Traditional Knowledge: Pathways to the Future. Geneva, Switzerland: ICTSD, p. 15.

${ }^{5}$ Carlos M Correa, (2001), Traditional Knowledge and Intellectual Property: Issues and Options Surrounding the Protection of Traditional Knowledge: a Discussion Paper. Geneva: Quaker United Nations Office, p. 5.
} 


\section{B. Discussion}

To protect the Traditional Knowledge (TK) related to Genetic Resources (GR), World Intellectual Property Organization (WIPO) generally proposes two forms of protection that are Positive and Defensive Protection. In establishing such protection, each protection model developed will depend on the circumstances and needs of each country. As suggested by Daniel Robinson ${ }^{6}$ there is no size fits all formula for TK protection.

Defensive protection of TK is one way to prevent third parties from obtaining or exercising invalid IPRs over the TK. It can be an effective way of blocking and preventing granted IP rights to the wrong parties. However, it does not automatically stop the misappropriation act on TK. It needs national regulations. There should be national regulations as the basic technical aspect for TK holders protection and advantages of implementation. Whereas TK legitimate rights admission is required both in IPRs and Sui generis regimes. In protecting TK, IPRs regime is reliable for several counties, for instance, Indonesia and Paraguay, according to CBD Report Secretariat. While, communal and writing deficiency as special traits of TK, the system of conventional intellectual property does not protect them properly. Lastly, the IPRs system which is impractical in protecting it, some developing counties awareness is raised in protecting $\mathrm{TK}$ to improve their sui generis system.

After the ratification of the Nagoya Protocol, next step that should be done by the Government of Indonesia is to implement the provisions of the Nagoya Protocol through national legislation and to prepare the supporting infrastructure both at national and regional level. Specifically, these elements are suggested to prevent the misappropriation of TK and ensure the equitable benefit sharing from the industrial and the commercial uses. What article 15 and Article 16 of the Nagoya Protocol mandates to the Parties shall take appropriate and proportionate national legislation on access and benefit sharing from the utilization of genetic resources and traditional knowledge related to genetic resources. In particular, as it aims to avoid TK trespass and confirm the fit profit sharing of industrial and commercial uses, the elements are recommended. As mandated in Article 15 and Article 16 of the Nagoya Protocol, proper and comparable national legislation are required to take by the parties. The Indonesian government is mandated to carry out the national development which is consecutive with national plan development

\footnotetext{
${ }^{6}$ Daniel Robinson, (2007), Exploring Components and Elements of Sui Generis Systems for Plant Variety Protection and Traditional Knowledge in Asia. Switzerland: ICTSD, p. 21.
} 
sustainability and set forward the points of Biodiversity Action Plan for Indonesia. It is the agreement gained based on the Indonesian Summit on Sustainable development (ISSD) on the 21 of January 2004 in Yogyakarta. ${ }^{7}$

\section{Amendments to the Patent Law}

IPRs is a necessary law when talking about ABS in genetic resources utilization associated with traditional knowledge. Trespassing/biopiracy on some traditional knowledge use and the commercialization come up from it are tied up. Biopiracy implementation legitimacy mostly involves the Patent Law in a lot of countries, such as in Indonesia. Traditional knowledge protection associated with genetic resources should unite with the use of the patent law that is very important particularly in the medical field in Indonesia. Inventors can protect the inventions through patent law. Otherwise, it becomes the implementation of biopiracy legitimacy as well as inequitable acts to particular countries (poor and developing countries).

In the context of Indonesia, biopiracy on the genetic resources related to traditional knowledge was caused by several provisions in Indonesian Patent Law No.13 of 2016. Several articles in Indonesian Patent Law have suspected the possibility to protect the traditional knowledge related to genetic resources in Indonesia. The curtain of those articles are:

First, the statement in Article 9 (b) that the invention associated with examination, treatment, and surgery methods adjust for humans or animals, the patent cannot be given. Conversely, the statement from Article 27 paragraph (3) TRIPs agreement that "....". The word "may" refers to countries which giving the patent in the invention are legal. In conclusion, it is possible allowed to give the patent in another country for any invention of examination, therapy, surgery, and treatment adjust for animals or human, though Indonesian Patent Law cannot protect it.

Second, the statement in Article 9 (e) which except microorganism as a patent for all living creatures, and primarily plants

\footnotetext{
${ }^{7}$ Suhartini. May $16^{\text {th }}$, (2009), "Peran Konservasi Keanekaragaman Hayati dalam Menunjang Pembangunan yang Berkelanjutan (The Role of Biodiversity Conservation in Supporting the Sustainable Development)". Proceedings of the National Seminar on Research, Education and the Application of Mathematics and Natural Sciences, Organized by Faculty of Mathematics and Natural Sciences - Yogyakarta State University. p. 204.
} 
or animal production by biological processes or microbiological processes. Nevertheless, in Indonesia, it is not allowed to patent, still, in another country it is potential. So that there are no international similarities resulted.

Third, the statement in Article 49 Paragraph (1) which require reasons for a patent refusal. It can be seen that it does not contain traditional knowledge according to the stipulation in Article 3 Paragraph (2) concerning Prior art, it is clear that traditional knowledge is excluding. It can be certain that the objection to one patent with the reason that the patent is lack of novelty due to it known since long times ago through the traditional knowledge, definitely cannot be accepted. Ineffectiveness of Patent Law that cannot protect the traditional knowledge, after ratified by the Nagoya Protocol, demanding to the Government of Indonesia to amendment the Patent Law. Moreover, to protect the traditional knowledge, except the amendment on several articles in Patent Law, some countries also had already been amended several regulations related to it. Those countries are India, ${ }^{8}$ Egypt,${ }^{9}$ South Africa, ${ }^{10}$ and Switzerland. ${ }^{11}$

Also, besides several articles amendment of Patent Law, some adjustments associated with it had also been amended by several countries in protecting traditional knowledge. They are India, Egypt, South Africa, and Switzerland.

a. It is required to attach the genetic resources origin source by foreign parties whose patent practice acquired from genetic resources use associated with traditional knowledge. There must be a refusal for unrevealed origin by the applicant.

b. It is required to attach the approval document of traditional knowledge from the owner as in the name of traditional knowledge by prior inform consent (PC) by foreign parties whose patent practice acquired from genetic resources use associated with traditional knowledge

c. It is obliged to contemplate traditional as a prior inform consent in the new Patent Law

\footnotetext{
${ }^{8}$ India protects their traditional knowledge related to genetic resources through the Patents Act 1970 as amended by Patents Act 2005, also through the sui generis law, Biological Diversity Law No. 18 of 2002.

${ }^{9}$ Egypt protects their traditional knowledge related to genetic resources through the Law on the Protection of Intellectual Property Rights, Law No. 82 of 2002.

${ }^{10}$ South Africa protects their traditional knowledge related to genetic resources through the Amendment of Patents Act 2005.

${ }^{11}$ Switzerland protects their traditional knowledge related to genetic resources through Federal Law of June 25, 1954 on Patents for Inventions (status as of January $1^{\text {st }}, 2012$ ).
} 
d. Fair and equal sharing of profit can be attached by foreign parties whose patent practice acquired from genetic resources use associated with traditional knowledge.

Also, according to the document of WIPO Intergovernmental Committee on Intellectual Property and Genetic Resources, Traditional and Folklore that states in the context of traditional knowledge protection should be undertaken comprehensively, potentially using both positive and defensive forms of protection. However, defensive protection is no substitute for positive protection, it intended as a preventive tool to preventing other parties from gaining intellectual property (IP) rights, ${ }^{12}$ and learn from the success of India through the Traditional Knowledge Digital Library (TKDL) in order to protect their traditional knowledge, thus the revision of Patent Law, it should be considered the information that sources from traditional database that recognizes by the Government of Indonesia as the prior art. Therefore, if in the future there is a cancellation of a patent application because the knowledge does lack novelty due to already known through traditional knowledge, it becomes acceptable and granted.

\section{Sui Generis Law}

Moreover, sui generis law can be considered as another adjustment by the government in protecting genetic resources associated with traditional knowledge so the patent law can be effective. It has been used by several CBD members, such as Brazil for utilizing Provisional Diversity Act No.2 186-16, August 23, 2001, India in the Biological Diversity Act, 2002 18, and The Philippines through the Indigenous People Rights Act, 1997 (Republic Act NO8371).

Sui generis development as the instrument to preserve traditional knowledge is according to the statement that the development of sui generis mechanism as well as the law of public IP to handle special practical needs or the aims of policy associated with subject matter contains specific legitimated stipulation and measures of implementation or administrative. It is stated in WIPO 3 committee of Intergovernmental on The Intellectual Property and Genetic Resources Traditional Knowledge and Folklore statement. ${ }^{13}$ To make it effective, some necessary questions which what content the system needs to have been identified as the government refers to the Committee's formulation in developing sui generis law. They are as follows:

a) What is the (policy) objective of the protection?

b) What is the subject matter?

\footnotetext{
${ }^{12} \mathrm{WIPO} / \mathrm{GRTKF} / \mathrm{IC} / 6 / 8$ (2004). Available at Secretariat of WIPO.

${ }^{13} \mathrm{WIPO} / \mathrm{GRTKF} / \mathrm{IC} / 3 / 8$ (June $13^{\text {th }}$ to $21^{\text {st }}, 2002$ ). Available at Secretariat of WIPO.
} 
c) What criteria should this subject matter meet to be protected?

d) Who owns the rights?

e) What are the rights?

f) How are the rights acquired?

g) How to administer and enforce the rights?; and

h) How are the rights lost or how do they expire? ${ }^{14}$

In line with it, it should also be noted that overall the most important substance to be aware of the sui generis law is the recognition of indigenous people as the owner of traditional knowledge. In addition to the above, according to Agus Sardjono, there is another important thing that should also be considered to establish the sui generis law related to traditional knowledge protection, which is as follows: ${ }^{15}$

1. To prevent the disintegration, it should be remembered that although the people of Indonesia consists of hundreds of tribes, the tribe is unity. It has the collective rights on the Indonesian's traditional knowledge including traditional medical knowledge. Thus, the knowledge of particular indigenous peoples, for example, the knowledge of Jamu is not the only Java's property but its shared heritage of the unity of the local Indonesian community. Hence, another Indonesian outside of Java also can use it.

2. Continual development of creativity of original local community is obliged to be confirmed in sui generis law. So that the traditional knowledge creativity development shall not be disrupted and Indonesian can conduct traditional medicine practice and development.

Moreover, in the level of implementing regulations, it can use the Government Regulation No. 41 of 2006 about Licensing to Conduct Research and Development for Foreign University, Foreign Research and Development Institute, Foreign Corporations, and Foreigner in Indonesia. It puts the obligation to the foreign parties to ask the research permission from the Government before they research Indonesia, including research related to the traditional knowledge related to genetic resources.

\section{Conclusion}

Traditional knowledge must have definite protection considering that traditional knowledge is one of the fundamental needed for human life. At least two kinds of positive protections that we can develop to protect TK related to GR optimizes the patent law and develop the sui generis law. Furthermore, it can be done by some revision by adding new substances, an improvement on the articles, or even by doing the deletion on certain articles. Moreover, in order to develop the sui generis law, it identified several

\footnotetext{
${ }^{14}$ Ibid, p. 16.

${ }^{15}$ Agus Sardjono, (2010), Hak Kekayaan Intelektual dan Pengetahuan Tradisional (Intellectual Property Rights and Traditional Knowledge). Bandung: Alumni, pp. 252-253.
} 
minimum elements that shall be contained on it, inter alia: the purposes of protection; scope of protection; criteria of protection; the beneficiaries of protection: the holder of traditional knowledge; the kind of rights to be granted; how the rights acquired; how to enforce it; how the rights lost or expired; and dispute resolution.

A. Book

\section{Bibliography}

Correa, Carlos M. (2001). Traditional Knowledge and Intellectual Property: Issues and Options Surrounding the Protection of Traditional Knowledge: a Discussion Paper. Geneva: Quaker United Nations Office.

Dutfield, Graham. (2006). Protecting Traditional Knowledge: Pathways to the Future. Switzerland: ICTSD.

Robinson, Daniel. (2007). Exploring Components and Elements of Sui Generis Systems for Plant Variety Protection and Traditional Knowledge in Asia. Switzerland: ICTSD.

Sardjono, Agus. (2010). Hak Kekayaan Intelektual dan Pengetahuan Tradisional (Intellectual Property Rights and Traditional Knowledge). Bandung: Alumni.

\section{B. Journal and Proceeding}

Fink, Carsten. Patent Protection, Transnational Corporations, and Market Structure: A Simulation Study of the India Pharmaceutical Industry, in Imas Rosidawati. (2013). "Konsep Perlindungan Pengetahuan Tradisional Berdasarkan Asas Keadilan melalui Sui Generis Intellectual Property System (The Concept of Traditional Knowledge Protection Based on the Principle of Justice through the Sui Generis of Intellectual Property System)", Jurnal Hukum Ius Quaiustum. 20(2)

Suhartini. May $16^{\text {th }}$. (2009). "Peran Konservasi Keanekaragaman Hayati dalam Menunjang Pembangunan yang Berkelanjutan (The Role of Biodiversity Conservation in Supporting the Sustainable Development)." Proceedings of the National Seminar on Research, Education and the Application of Mathematics and Natural Sciences, Organized by Faculty of Mathematics and Natural Sciences - Yogyakarta State University.

\section{World Wide Web}

http://www.wipo.int/tk/en/genetic/ accessed on 22-08-2017. 
WIPO Publication No. 920 Booklet No. 2. Available at the Secretariat of WIPO.

WIPO/GRTKF/IC/3/8 (June $13^{\text {th }}$ to $\left.21^{\text {st }}, 2002\right)$. Available at the Secretariat of WIPO.

WIPO/GRTKF/IC/6/8 (2004). Available at the Secretariat of WIPO. 